\title{
Quality of life among patients with left ventricular assist device: Comparison of two populations
}

\author{
Sol ventrikül destek cihazlı hastalarda yașam kalitesi: Iki toplumun karșılaștırılması
}

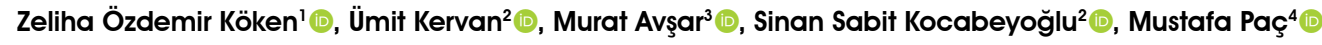 \\ Institution where the research was done: \\ Türkiye Yüksek intisas Training and Research Hospital, Department of Cardiovascular Surgery, Ankara, Turkey \\ Hannover Medical School, Cardiothoracic, Transplantation and Vascular Surgery, Hannover, Germany
}

Author Affiliations:

'Department of Surgical Nursing, Hacettepe University Faculty of Nursing, Ankara, Turkey ${ }^{2}$ Department of Cardiovascular Surgery, University of Health Sciences, Ankara City Hospital, Ankara, Turkey ${ }^{3}$ Department of Cardiothoracic, Transplantation and Vascular Surgery, Hannover Medical School, Hannover, Germany ${ }^{4}$ Department of Cardiovascular Surgery, Yüksek Ihtisas University, Faculty of Medicine, Ankara, Turkey

\begin{abstract}
Background: This study aims to evaluate quality of life among patients with an implanted left ventricular assist device in two different populations.

Methods: This cross-sectional study included a total of 20 patients (15 males, 5 females; mean age $41.8 \pm 13.4$ years; range, 20 to 65 years) from Turkey and 40 patients (33 males, 7 females; mean age 55.1 \pm 11.6 years; range, 21 to 76 years) from Germany who underwent left ventricular assist device implantation and reached their third month of treatment between January 2016 and August 2016. The Euro Quality of Life-5 Dimension Questionnaire and Kansas City Cardiomyopathy Questionnaire-12 were used to assess quality of life of both groups.

Results: Sixty-five percent of the German patients returned to work, while none of the Turkish patients returned after implantation $(\mathrm{p}=0.000)$. The Turkish $(70 \%)$ and German $(40 \%)$ patients reported that they had difficulty in living with a left ventricular assist device $(\mathrm{p}=0.028)$. The mean Euro Quality of Life-5 Dimension Questionnaire visual analog scale scores of the Turkish and German patients were $70.50 \%$ and $62.38 \%$, respectively. The mean Kansas City Cardiomyopathy Questionnaire-12 scores of the Turkish patients were significantly higher than those of the German patients $(\mathrm{p}=0.01)$.

Conclusion: Left ventricular assist device implantation improved the quality of life of both Turkish and German patients. Turkish patients with left ventricular assist device should be encouraged to adopt a more independent life, not to limit their lives to home and to return to work according to their functional capacity.
\end{abstract}

Keywords: Left ventricular assist device, mechanical support, population, quality of life.

\section{$\ddot{O} Z$}

Amaç: Bu çalışmada iki farklı toplumda sol ventrikül destek cihazı takılan hastalarda yaşam kalitesi değerlendirildi.

Çalışma planı: Bu kesitsel çalışmaya Ocak 2016 ile Ağustos 2016 tarihleri arasında sol ventrikül destek cihazı takılan ve tedavinin üçüncü ayına ulaşan Türkiye'den toplam 20 hasta (15 erkek, 5 kadın; ort. yaş $41.8 \pm 13.4$ yıl; dağ 11 ım, 20-65 yıl) ve Almanya'dan 40 hasta (33 erkek, 7 kadın; ort. yaş $55.2 \pm 11.6$ yıl; dağılım, 21-76 yıl) alındı. Her iki grubun yaşam kalitesinin değerlendirilmesinde Avrupa Yaşam Kalitesi-5 Boyut Anketi ve Kansas City Kardiyomiyopati Anketi-12 kullanıldı.

Bulgular: Alman hastaların \%65'i implantasyon sonrasında işe geri dönerken, Türk hastaların hiçbiri işe geri dönmedi $(\mathrm{p}=0.000)$. Türk (\%70) ve Alman (\%40) hastalar sol ventrikül destek cihazı ile yaşamakta zorlandıklarını ifade etti $(\mathrm{p}=0.028)$. Avrupa Yaşam Kalitesi-5 Boyut Anketi görsel analog ölçeği skoru ortalaması Türk hastalarda \%70.50, Alman hastalarda ise $\% 62.38$ idi. Kansas City Kardiyomiyopati Anketi-12 ortalama skoru, Alman hastalara kıyasla, Türk hastalarda anlamlı şekilde yüksek idi $(\mathrm{p}=0.01)$.

Sonuç: Sol ventrikül destek cihazı implantasyonu Türk ve Alman hastaların her ikisinde de yaşam kalitesini iyileştirdi. Sol ventrikül destek cihazı olan Türk hastalar, daha bağımsız bir yaşamı benimseme, yaşantılarını ev ile sınırlandırmama ve fonksiyonel kapasiteleri doğrultusunda işe geri dönme konularında cesaretlendirilmelidir.

Anahtar sözcükler: Sol ventrikül destek cihazı, mekanik destek, toplum, yaşam kalitesi.

Received: July 30, 2019 Accepted: November 15, 2019 Published online: April 22, 2020

Correspondence: Zeliha Özdemir Köken, PhD. Hacettepe Üniversitesi Hemşirelik Fakültesi Cerrahi Hastalıkları Hemşireliği Anabilim Dalı, 06230 Altındağ, Ankara, Türkiye. Tel: +90505-586 6346 e-mail: ozdemir.z@hotmail.com 
Ventricular assist devices (VADs) are widely used for short or long periods in patients who are or may be candidates for heart transplantation. ${ }^{[1,2]}$ These devices do not only prolong the lives of patients with end-stage heart failure, but also improve their quality of life (QoL). ${ }^{[1,3-5]}$ Allen et al. ${ }^{[6]}$ reported that left ventricular assist devices (LVADs) provide a good QoL and allow patients to spend more time outside the hospital. The Interagency Registry for Mechanically Assisted Circulatory Support (INTERMACS) study showed a significant improvement in the QoL of patients in the third month after LVAD implantation, compared to the pre-treatment period. ${ }^{[7]}$ Although LVADs increase life expectancy and improve QoL, they have been reported to cause various complications, such as post-implantation infections, thromboembolic events, and device dependency. Therefore, further researches comparing pre- and post- implantation of LVAD outcomes in terms of QoL are warranted. Previous studies have mostly examined the QoL of individuals in a certain population using different QoL scales. ${ }^{[3,4,6,8]}$

The perceptions, expectations, and needs of patients with LVAD regarding QoL may vary across countries. In the present study, we aimed to evaluate QoL of patients with LVAD in two different populations.

\section{PATIENTS AND METHODS}

This cross-sectional study was conducted in two centers in Germany and Turkey between January 2016 and August 2016. A total of 20 patients (15 males, 5 females; mean age $41.8 \pm 13.4$ years; range, 20 to 65 years) from Turkey and 40 patients ( 33 males, 7 females; mean age 55.1 \pm 11.6 years; range, 21 to 76 years) from Germany were included in the study. Data were collected through face-to-face interviews with patients who met the inclusion criteria and agreed to participate in the study. Patients who were admitted to the outpatient clinic were interviewed in a separate room in each study center. Each interview lasted about $30 \mathrm{~min}$. A written informed consent was obtained from each patient. The study protocol was approved by the Non-Interventional Clinical Studies Ethics Committee of Türkiye Yüksek İhtisas Training and Research Hospital (No: 2016/53). Additionally, in accordance to local German protocols study approval by the institutional ethical review board was waived given its non-interventional design. The study was conducted in accordance with the principles of the Declaration of Helsinki.

Patients were considered eligible for participation in the study if they were 18 years of age or older and literate; had no communication difficulties and psychological and mental problems; and reached their third month of treatment. In routine practice, LVADs are implanted in 25 to 30 patients every year in the center in Turkey as bridge-to-transplant or destination therapy. A patient who is eligible for LVAD implantation is operated after preoperative preparation and is followed in the intensive care unit for a few days after the operation. The patient is also followed in the clinic for a few weeks after intensive care and the patient and caregiver are provided with information and instructions (i.e., function of the device, mechanism of operation, possible complications and technical problems, post-discharge lifestyle, dressing, outpatient clinic, and emergency procedures). When ready, the patient is discharged and called for examination once or twice a month. The LVADs are implanted in about 100 patients every year in the center in Germany. Patients undergoing LVAD implantation are hospitalized for three weeks and, then, referred to the rehabilitation clinic. Patients remain in the rehabilitation center, until they are fully adapted to live with the device. In the post-discharge period, they are examined in the outpatient clinic every six weeks.

\section{Instruments and measures}

Data were collected using a Descriptive Characteristics Information Form, Euro Quality of Life-5D Questionnaire (EQ-5D) and Kansas City Cardiomyopathy Questionnaire-12 (KCCQ-12).

Descriptive Characteristics Information Form: The questionnaire developed by the researchers consists of 18 questions to identify the socio-demographic characteristics of patients. It also includes a visual numeric scale to assess the well-being of patients pre- and post- LVAD implantation. This scale was previously used to present patients' pre- and postLVAD feelings as quantitative data. ${ }^{[9]}$ The questionnaire written in Turkish was adapted to German by the researchers.

EQ-5D: It is a general health scale used to measure QoL. It was first developed in 1987 and translated into more than 60 languages by the EuroQoL Working Group. The German and Turkish versions of the scale were used in the study. The scale consists of two parts as follows: ${ }^{[10]}$

The EQ-5D index scale consists of five dimensions including mobility, self-care, usual activities, pain/discomfort and anxiety/depression. Each dimension has three levels: no problems, some problems, extreme problems.

The EQ-5D visual analog scale (VAS) is a visual analog scale recording patients' self-rated health on a vertical thermometer-like scale scored from 0 to 100 indicating QoL scores. 
KCCQ-12: It is a 12-item scale developed to assess how heart failure affects patients' lives. Item 1 deals with physical limitation, items $2,3,4$, and 5 deal with symptom frequency, and items 6 and 7 deal with QoL. Three separate scores are obtained from these items and a total score is, then, calculated from these three scores, the lowest score being 0 and the highest score being 100. The higher the score, the better the QoL. The German and Turkish versions of the scale were used in the study. ${ }^{[11]}$

\section{Statistical analysis}

Statistical analysis was performed using the IBM SPSS for Windows version 22.0 software (IBM Corp., Armonk, NY, USA). Continuous variables were expressed in mean \pm standard deviation $(\mathrm{SD})$ or median (min-max), while categorical data were expressed in number and frequency. An independent groups t-test, Mann-Whitney U test, and chi-square test were used for comparisons between countries. The Spearman's correlation coefficient and linear regression analysis were used to analyze the possible relationships between the variables. A $p$ value of $<0.05$ was considered statistically significant.

\section{RESULTS}

\section{Patient demographics}

Table 1 shows the descriptive characteristics of the participants. Both populations groups were similar in gender, marital status, and educational status (Table 1). There was a statistically significant difference in the

Table 1. Descriptive characteristics of study population

\begin{tabular}{|c|c|c|c|c|c|c|c|c|c|c|c|}
\hline \multirow[b]{2}{*}{ Variables } & \multicolumn{5}{|c|}{ Turkish population $(\mathrm{n}=20)$} & \multicolumn{5}{|c|}{ German population $(n=40)$} & \multirow[b]{2}{*}{$p$} \\
\hline & $\mathrm{n}$ & $\%$ & Mean \pm SD & Median & IOR & $\mathrm{n}$ & $\%$ & Mean \pm SD & Median & IOR & \\
\hline Age (year) & & & $41.8 \pm 13.4$ & & & & & $55.2 \pm 11.6$ & & & 0.000 \\
\hline Duration on LVAD (day) & & & & 300 & $180-352$ & & & & 750 & $360-1342$ & 0.059 \\
\hline Gender & & & & & & & & & & & 0.494 \\
\hline Female & 5 & 25.0 & & & & 7 & 17.5 & & & & \\
\hline Male & 15 & 75.0 & & & & 33 & 82.5 & & & & \\
\hline Family status & & & & & & & & & & & 0.462 \\
\hline Married & 14 & 70.0 & & & & 23 & 57.5 & & & & \\
\hline Single & 6 & 30.0 & & & & 17 & 42.5 & & & & \\
\hline Educational level & & & & & & & & & & & 0.659 \\
\hline Primary education & 11 & 55.0 & & & & 21 & 52.5 & & & & \\
\hline High school & 6 & 30.0 & & & & 13 & 32.5 & & & & \\
\hline University & 3 & 15.0 & & & & 6 & 15.0 & & & & \\
\hline Work status & & & & & & & & & & & 0.000 \\
\hline Working & 0 & 0.0 & & & & 26 & 65.0 & & & & \\
\hline Not working & 20 & 100 & & & & 14 & 35.0 & & & & \\
\hline $\begin{array}{l}\text { LVAD-related problems after } \\
\text { discharge }\left(\text { Turkey }=6^{*}, \text { Germany }=19^{*}\right)\end{array}$ & & & & & & & & & & & 0.041 \\
\hline Infection & 4 & 66.6 & & & & 7 & 36.8 & & & & \\
\hline Thromboembolic event & 3 & 50.0 & & & & 2 & 10.5 & & & & \\
\hline Bleeding & 2 & 33.3 & & & & 0 & 0.0 & & & & \\
\hline $\begin{array}{l}\text { Technical problem } \\
\text { (batteries and/or controller) }\end{array}$ & 0 & 0.0 & & & & 11 & 57.8 & & & & \\
\hline Having difficulty in living with LVAD & & & & & & & & & & & 0.028 \\
\hline Yes & 14 & 70.0 & & & & 16 & 40.0 & & & & \\
\hline No & 6 & 30.0 & & & & 24 & 60.0 & & & & \\
\hline \multicolumn{12}{|l|}{ LVAD strategy } \\
\hline Bridge-to-transplant & 17 & 85.0 & & & & 24 & 60.0 & & & & \\
\hline Bridge-to-transplant candidacy & 2 & 10.0 & & & & 1 & 2.5 & & & & \\
\hline Destination therapy & 1 & 5.0 & & & & 15 & 37.5 & & & & \\
\hline \multicolumn{12}{|l|}{ LVAD type } \\
\hline Heart Ware ${ }^{\circledR}$ & 16 & 80.0 & & & & 23 & 57.5 & & & & \\
\hline Heart Mate II ${ }^{\circledR}$ & 1 & 5.0 & & & & 14 & 35.0 & & & & \\
\hline Heart Mate III ${ }^{\circledR}$ & 3 & 15.0 & & & & 1 & 2.5 & & & & \\
\hline Reliant Heart $^{\circledR}$ & 0 & 0.0 & & & & 2 & 5.0 & & & & \\
\hline
\end{tabular}

SD: Standard deviation; IQR: Interquartile range; LVAD: Left ventricular assist device; * $\mathrm{n}$ duplicated. 


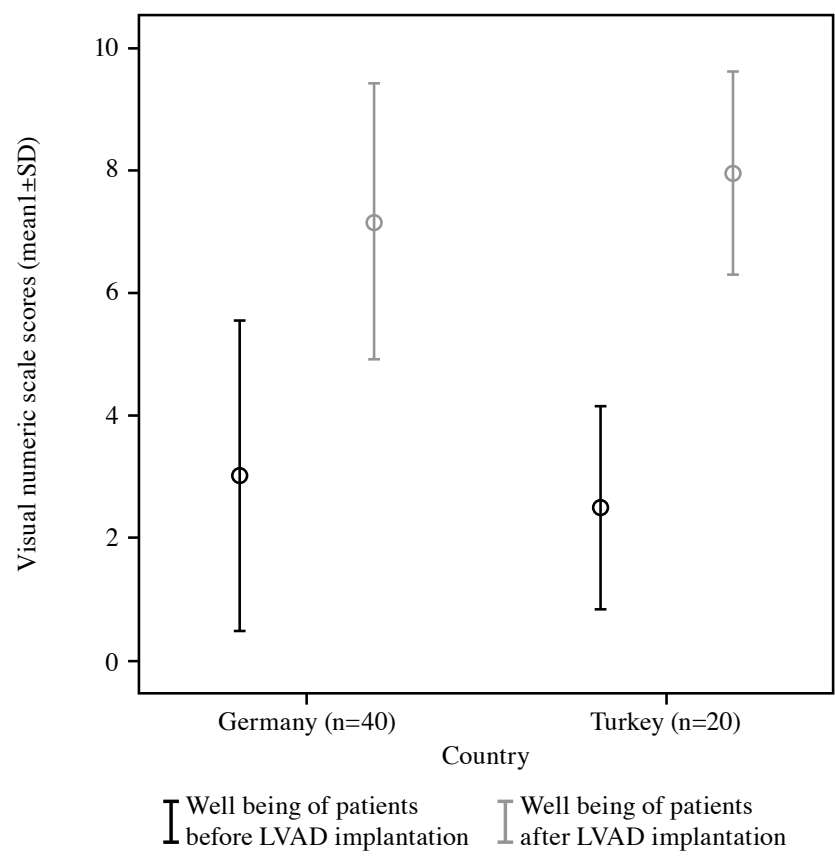

Figure 1. Visual numeric scale scores of patients before and after LVAD.

SD: Standard deviation; LVAD: Left ventricular assist device.

post-LVAD implantation between the employment status two groups. None of the Turkish participants returned to the work after implantation, while most of the German participants did. There was also a statistically significant difference in the post-LVAD complications between the two groups. The Turkish participants mostly had infections, while the German participants had technical problems with controller and/or batteries. A total of $70 \%$ of the Turkish patients and $40 \%$ of the German patients had difficulty in living with LVAD. In the Turkish population, LVAD was mostly used for bridge-to-transplant therapy, while it was used for bridge-to-transplant and destination therapy in the German group. A visual numeric scale was used to assess the Turkish and German patients' pre- and postoperative well-being. The results showed no statistically significant difference between the two groups $(p=0.763)$, indicating that the well-being of both groups improved after LVAD implantation (Figure 1).

\section{QoL outcomes}

The EQ-5D and KCCQ-12 scales were used to assess participants' QoL. According to the subscales of the EQ-5D, both groups had low post-LVAD implantationrelated extreme problems scores. However, The Turkish patients had higher scores of moderate problems on the subscales of self-care and usual activities than the German population (Table 2). On the other hand, the German patients had higher scores of moderate problems on the subscales of pain/discomfort and anxiety/depression than the Turkish patients (Table 2). Table 2 shows the EQ-5D VAS scores of the two groups, indicating that the Turkish participants had a higher mean well-being score than the German participants, despite the lack of statistically significant difference in the EQ-5D VAS scores between the two groups $(\mathrm{p}=0.077)$.

Table 3 shows the KCCQ-12 QoL scale scores. The total scores obtained from the subscales showed a statistically significant difference between the two groups $(\mathrm{p}=0.001)$. While there was no

Table 2. Numbers (percentages) of participants reporting a problem in each EQ-5D subdimensions and EQ-5D VAS scores ( $n_{\text {Turkey }}=20, n_{\text {Germany }}=40$ )

\begin{tabular}{|c|c|c|c|c|c|c|c|c|c|c|c|c|}
\hline \multirow{3}{*}{ EQ-5D Dimension } & \multicolumn{4}{|c|}{ Any problem } & \multicolumn{4}{|c|}{ Moderate problem } & \multicolumn{4}{|c|}{ Extreme problem } \\
\hline & \multicolumn{2}{|c|}{$\begin{array}{c}\text { Turkish } \\
\text { population }\end{array}$} & \multicolumn{2}{|c|}{$\begin{array}{c}\text { German } \\
\text { population }\end{array}$} & \multicolumn{2}{|c|}{$\begin{array}{c}\text { Turkish } \\
\text { population }\end{array}$} & \multicolumn{2}{|c|}{$\begin{array}{c}\text { German } \\
\text { population }\end{array}$} & \multicolumn{2}{|c|}{$\begin{array}{c}\text { Turkish } \\
\text { population }\end{array}$} & \multicolumn{2}{|c|}{$\begin{array}{c}\text { German } \\
\text { population }\end{array}$} \\
\hline & $\mathrm{n}$ & $\%$ & $\mathrm{n}$ & $\%$ & $\mathrm{n}$ & $\%$ & $\mathrm{n}$ & $\%$ & $\mathrm{n}$ & $\%$ & $\mathrm{n}$ & $\%$ \\
\hline Mobility & 10 & 50.0 & 20 & 50.0 & 10 & 50.0 & 20 & 50.0 & 0 & 0.0 & 0 & 0.0 \\
\hline Self-care & 7 & 35.0 & 22 & 55.0 & 13 & 65.0 & 15 & 37.5 & 0 & 0.0 & 3 & 7.5 \\
\hline Usual activities & 5 & 25.0 & 13 & 32.5 & 15 & 75.0 & 23 & 57.5 & 0 & 0.0 & 4 & 10.0 \\
\hline Pain/discomfort & 11 & 55.0 & 12 & 30.0 & 9 & 45.0 & 24 & 60.0 & 0 & 0.0 & 2 & 5.0 \\
\hline \multirow[t]{3}{*}{ Anxiety/depression } & 12 & 60.0 & 21 & 52.5 & 7 & 35.0 & 17 & 42.5 & 1 & 5.0 & 2 & 5.0 \\
\hline & \multicolumn{4}{|c|}{ Turkish population } & \multicolumn{4}{|c|}{ German population } & & & & \\
\hline & \multicolumn{4}{|c|}{ Mean \pm SD } & \multicolumn{4}{|c|}{ Mean \pm SD } & \multicolumn{4}{|c|}{$p$} \\
\hline EQ-5D VAS & \multicolumn{4}{|c|}{$70.5 \pm 15.0$} & \multicolumn{4}{|c|}{$62.4 \pm 18.8$} & \multicolumn{4}{|c|}{0.077} \\
\hline
\end{tabular}

EQ-5D: EuroQoL-5 Dimension; VAS: Visual analog scale; SD: Standard deviation. 
Tablo 3. $K C C Q-12$ scores $\left(n_{\text {Turkey }}=20, n_{\text {Germany }}=40\right)$

\begin{tabular}{lcccccc}
\hline & \multicolumn{2}{c}{ Turkish population } & & \multicolumn{2}{c}{ German population } & \\
\cline { 2 - 3 } & Median & IQR & & Median & IQR & \\
\hline Physical limitation & 66.6 & 22.9 & & 41.6 & 41.6 & 0.001 \\
Symptom frequency & 89.1 & 20.0 & & 66.0 & 37.5 & 0.000 \\
Quality of life & 62.5 & 43.8 & & 50.0 & 37.5 & 0.172 \\
Social limitation & 58.3 & 41.6 & & 41.6 & 33.3 & 0.088 \\
Summary score & 70.6 & 24.5 & & 51.8 & 26.7 & 0.001 \\
\hline
\end{tabular}

KCCQ: Kansas City Cardiomyopathy Questionnaire-12; IQR: Interquartile range.

statistically significant difference in the QoL and social limitation subscale scores between the two groups, there was a statistically significant difference in the physical limitation $(\mathrm{p}=0.001)$ and symptom frequency $(\mathrm{p}=0.001)$ subscale scores between them (Table 3). In addition, the German participants had lower mean scores on all subscales and, therefore, had lower self-rated QoL scores than the Turkish participants (Table 3).

\section{DISCUSSION}

Previous studies have shown that ventricular assist devices improve QoL in older and younger patients from before to six months after LVAD implantation, and older patients report more problems with mobility early after implant than younger patients. ${ }^{[12]}$ In this study, the mean age of the German population was higher than the Turkish population. The German group had significantly lower scores on the KCCQ subscales of physical limitation and symptom frequency, consistent with the literature. ${ }^{[12]}$

Patients with LVAD are expected to continue their lives with the device after rehabilitation. Patients can return to work three to six months after LVAD implantation. ${ }^{[12,13]}$ This study revealed a statistically significant difference in the working status between the two patient groups. Most of the German patients returned to work earlier after LVAD implantation, while the Turkish patients did not. This may be due to the fact that having to live with LVAD is perceived by the Turkish society as an obstacle to work. In addition, social insurance and pension status should be taken into consideration while evaluating the employment status. Heart failure is grounds for early retirement for patients working in Turkey, and it is similar in Germany. ${ }^{[14]}$ In both countries, patients with heart failure who were implanted LVAD have the option of early retirement. One of the most important purposes of LVAD in patients with end-stage heart failure is to improve their physical capacity. ${ }^{[1,2]}$ Therefore, patients with LVAD should be encouraged to resume their preillness lives and return to the work, albeit within the limits of their physical capacities.

The most common post-LVAD complications include bleeding, infection, thromboembolic events, and LVAD-related technical problems. ${ }^{[15]}$ Complications seen in both groups in this study were similar to those reported in the literature. ${ }^{[15]}$ There was, however, a significant difference in the frequency of complications between the two groups. The most common post-discharge complications in the Turkish patients was infections, while it was LVAD-related technical problems due to changes of the controller and/or batteries in the German patients. The fact that duration on LVAD of German patients was longer than the Turkish patients accounts for the technical problems in the German group in this study.

In the present study, we observed that the Turkish patients had statistically significantly more difficulty in living with LVAD than the German patients. Physical and psychosocial rehabilitation support provided to patients at rehabilitation centers after LVAD implantation and before hospital discharge improves their QoL by facilitating their adaptation to their new lives. ${ }^{[16]}$ Most patients in Germany are referred to rehabilitation centers after LVAD implantation and are followed, until they are ready to go home. ${ }^{[17]}$ However, the number of such rehabilitation centers in Turkey is scarce, which might be the reason why Turkish patients had more difficulty in living with LVAD after discharge.

Studies on post-LVAD QoL using the EQ-5D scale have demonstrated that pre-LVAD patients have extreme problems with mobility, self-care, usual activities, pain/ discomfort, and anxiety/depression; however, these problems are less frequent at the third and sixth month of implantation. ${ }^{[12,18]}$ Similar to the literature, neither of the two groups in this study reported extreme problems 
with the subscales of the EQ-5D. However, the Turkish patients had higher moderate problems scores on the subscales of self-care and usual activities than the German patients. This difference might be due to the fact that the Turkish society relies on family support for care and, therefore, patients may feel dependent on others for self-care and usual activities. ${ }^{[19,20]}$ Patients with LVAD should, therefore, achieve independence for self-care and usual activities to be able to return to normal life. At this point, training and psychosocial support are of utmost importance for patients to develop self-care skills and to be less dependent on caregivers. The EQ-5D VAS scores gives information about the patients' view of their own health. ${ }^{[10]}$ In the study of Grady et al., ${ }^{[12]}$ the mean VAS score was almost 62 at three months of LVAD implantation. In our study, participants evaluated their health status as good according to the EQ-5D VAS scores in both populations. Although the mean EQ-5D VAS score of the Turkish patients was higher than the German patients, the difference was not statistically significant.

The mean total scores of both groups on the KCCQ12 scale are similar to those reported by studies on the QoL of patients with LVAD. ${ }^{[18,21]}$ The KCCQ-12 scores showed that the Turkish group had higher mean scores on all subscales than the German group, indicating that the former had higher self-rated QoL than the latter. However, the Turkish group had significantly higher scores on the subscales of physical limitation and symptom frequency, and higher total scores on the entire scale than the German group. Despite high QoL scores on the KCCQ-12 scale, the Turkish patients had difficulty in living with LVAD, were unable to return to the work (Table 1), and had moderate problems with self-care and usual activities (Table 2). Patients in Turkey usually restrict their lives to home and immediate surroundings to avoid complications, expect for family support to meet their care needs and do not return to the work. ${ }^{[20,22]}$ The reason why the Turkish patients with LVAD had higher self-rated QoL might be that they adapted to this limited conditions. Of note, LVADs can be used for different purposes such as bridge-to-transplant, destination therapy, and bridge-to-candidacy in patients with severe heart failure. The sixth INTERMACS annual report states that destination therapy strategy continues to represent a major proportion of overall implants. ${ }^{[23]}$ In this study, the bridge-to-transplant strategy was mostly used in both Turkish and German groups. However, the number of patients who were implanted LVAD with the destination therapy strategy was higher in the German group than in the Turkish group. Grady et al. ${ }^{[12]}$ reported that QoL scores of patients who were implanted with a destination therapy were lower than the other groups. In this study, lower scores on the KCCQ subscales of physical limitation and symptom frequency of the German group are thought to be related to the number of patients with destination therapy.

Nonetheless, this study has a small sample size with a single-center design. Therefore, the results cannot be generalized to the overall population. Further largescale, prospective studies are needed to confirm these findings.

In conclusion, one of the main goals of left ventricular assist devices in patients with end-stage heart failure is to increase the physical capacity and quality of life. Quality of life for patients with left ventricular assist device may vary according to the populations in which they live and their expectations of life. In our study, left ventricular assist device implantation improved the quality of life of both Turkish and German patients. However, the Turkish patients with left ventricular assist device should be encouraged to adopt a more independent life, not to limit their lives to home and to return to work according to their functional capacity.

\section{Acknowledgment}

The authors would like to thank Prof. Dr. J. D. Schmitto, MD, $\mathrm{PhD}, \mathrm{MBA}$ and Hava Mannel, RN and Yeşim Aslan, RN for their support and help with the administration of the study.

\section{Declaration of conflicting interests}

The authors declared no conflicts of interest with respect to the authorship and/or publication of this article.

\section{Funding}

The authors received no financial support for the research and/or authorship of this article.

\section{REFERENCES}

1. Rose EA, Gelijns AC, Moskowitz AJ, Heitjan DF, Stevenson LW, Dembitsky W, et al. Long-term use of a left ventricular assist device for end-stage heart failure. $\mathrm{N}$ Engl J Med 2001;345:1435-43.

2. Yılmaz MB, Akar RA, Ekmekçi A, Nalbantgil S, Sade LE, Eren M, et al. Future of advanced heart failure and mechanical support devices: A Cardiology-Cardiovascular Surgery Consensus Report. Turk Gogus Kalp Dama 2016;24:201-2.

3. Boyle AJ, Ascheim DD, Russo MJ, Kormos RL, John R, Naka Y, et al. Clinical outcomes for continuous-flow left ventricular assist device patients stratified by pre-operative INTERMACS classification. J Heart Lung Transplant 2011;30:402-7.

4. Kirklin JK, Naftel DC, Kormos RL, Stevenson LW, Pagani FD, Miller MA, et al. Third INTERMACS Annual Report: 
the evolution of destination therapy in the United States. J Heart Lung Transplant 2011;30:115-23.

5. Maciver J, Ross HJ. Quality of life and left ventricular assist device support. Circulation 2012;126:866-74.

6. Allen JG, Weiss ES, Schaffer JM, Patel ND, Ullrich SL, Russell SD, et al. Quality of life and functional status in patients surviving 12 months after left ventricular assist device implantation. J Heart Lung Transplant 2010;29:278-85.

7. Kirklin JK, Pagani FD, Kormos RL, Stevenson LW, Blume ED, Myers SL, et al. Eighth annual INTERMACS report: Special focus on framing the impact of adverse events. J Heart Lung Transplant 2017;36:1080-6.

8. Jakovljevic DG, McDiarmid A, Hallsworth K, Seferovic PM, Ninkovic VM, Parry G, et al. Effect of left ventricular assist device implantation and heart transplantation on habitual physical activity and quality of life. Am J Cardiol 2014;114:88-93.

9. Aitken RC. Measurement of feelings using visual analogue scales. Proc R Soc Med 1969;62:989-93.

10. EQ-5D-3L Scale. Available at: http://www.euroqol.org/home. html. [Accessed: October, 2015.

11. Green CP, Porter CB, Bresnahan DR, Spertus JA. Development and evaluation of the Kansas City Cardiomyopathy Questionnaire: a new health status measure for heart failure. J Am Coll Cardiol 2000;35:1245-55.

12. Grady KL, Sherri W, Naftel DC, Myers S, Gelijins A, Moskowitz A, et al. Age and gender differences and factors related to change in health-related quality of life from before to 6 months after left ventricular assist device implantation: Findings from Interagency Registry for Mechanically Assisted Circulatory Support. J Heart Lung Transplant 2016;35:777-88.

13. Cook JL, Colvin M, Francis GS, Grady KL, Hoffman TM, Jessup M, et al. Recommendations for the Use of Mechanical Circulatory Support: Ambulatory and Community Patient Care: A Scientific Statement From the American Heart Association. Circulation 2017;135:e1145-e58.

14. Hostenkamp G, Stolpe M. The Social Costs of Health-related
Early Retirement in Germany: Evidence from the German Socio-Economic Panel. Journal of Applied Social Science Studies 2012;132:323-57.

15. Kilic A, Acker MA, Atluri P. Dealing with surgical left ventricular assist device complications. J Thorac Dis 2015;7:2158-64.

16. Mahfood Haddad T, Saurav A, Smer A, Azzouz MS, Akinapelli A, Williams MA, et al. Cardiac Rehabilitation in Patients With Left Ventricular Assist Device: A Systematic review and meta-analysis. J Cardiopulm Rehabil Prev 2017;37:390-6.

17. Willemsen D, Cordes C, Bjarnason-Wehrens B, Knoglinger E, Langheim E, Marx R, et al. Rehabilitation standards for follow-up treatment and rehabilitation of patients with ventricular assist device (VAD). Clin Res Cardiol Suppl 2016;11:2-49.

18. Emin A, Rogers CA, Banner NR; Steering Group, UK Cardiothoracic Transplant Audit. Quality of life of advanced chronic heart failure: medical care, mechanical circulatory support and transplantation. Eur J Cardiothorac Surg 2016;50:269-73.

19. Kara Kaşikçi M, Alberto J. Family support, perceived self-efficacy and self-care behaviour of Turkish patients with chronic obstructive pulmonary disease. J Clin Nurs 2007; 16:1468-78.

20. Güleç C. A Transcultural Perspective to the Disease and Health Concepts in the Anatolian Culture. J Clin Psy 2000;3:34-9.

21. Starling RC. Improved quantity and quality of life: a winning combination to treat advanced heart failure. J Am Coll Cardiol 2010;55:1835-6.

22. Yapic1 S. Relationship Between Family and Education in The Turkish Society. Turkish Studies International Periodical for the Languages. Turkish Studies - Language and Literature 2010;5:1544-70.

23. Kirklin JK, Naftel DC, Pagani FD, Kormos RL, Stevenson LW, Blume ED, et al. Sixth INTERMACS annual report: a 10,000-patient database. J Heart Lung Transplant 2014;33:555-64. 